\title{
LAMA PEMAKAIAN KONTRASEPSI SUNTIK BERHUBUNGAN DENGAN KEJADIAN AMENORE PADA AKSEPTOR SUNTIK
}

\author{
Mutia, Kamsatun \\ Poltekkes Kemenkes Bandung \\ Email: Kamsatun70@gmail.com
}

\begin{abstract}
One of the scope of reproductive health is the mother health service that support for healthy living and able to give birth to a healthy generation and quality. The family planning program $(K B)$ is an attempt to regulate pregnancy, the number of children, and distance of child birth to realize the quality family. Family Planning Program is also a strategy to reduce maternal mortality rate especially with 4 T mother condition; too young to give birth (under 20 years of age), overeat, too close to birth spacing, and too old childbirth (over 35 years of age). The use of injectable contraception is choice of contraception most in the city of Bandung .

This study aims to determine the relationship between the use of injectable contraception with the incidence of amenorrhea. The cross sectional study method. The independent variable is the duration of the use of injectable contraception, the dependent variable is the incidence amenore. The population in this study were all injecting contraception users in $R W 06$ Kelurahan Campaka with purposive sampling. Total sample that is 5 to 6 people. The instruments used in these two variables are interview guidelines and record medical .

Analysis using Chi Square test. Results terdapat research ties between prolonged use of injectable contraceptives with the incidence of amenorrhea, with $p$ value 0,000. As prevention of droup out on acceptor, then counseling should be done by power health take precedence and focus on replacementmethod contraception on acceptor the vulnerable there was a drop out that is acceptor the aged $>35$ years.
\end{abstract}

Keywords : Contraception Injection, amenorrhea, acceptor

\section{ABSTRAK}

Salah satu ruang lingkup kesehatan reproduksi ialah pelayanan kesehatan ibu yang dilakukan agar ibu mendapat pelayanan kesehatan yang menunjang untuk hidup sehat dan mampu melahirkan generasi yang sehat dan berkualitas. Program keluarga berencana (KB) merupakan usaha untuk mengatur kehamilan, jumlah anak, dan jarak kelahiran anak untuk mewujudkan keluarga yang berkualitas. Program KB juga merupakan strategi untuk mengurangi angka kematian ibu khususnya dengan kondisi ibu yang 4T; terlalu muda melahirkan (dibawah usia 20 tahun), terlalu sering melahirkan, terlalu dekat jarak melahirkan, dan terlalu tua melahirkan (diatas usia 35 tahun).. Penggunaan kontrasepsi suntik merupakan pilihan kontrasepsi terbanyak di Kota Bandung. Kontrasepsi suntik mempunyai efek samping, salah satunya adalah amenore yang timbul setelah beberapa lama pemakaian. Efek samping ini menjadi masalah untuk beberapa akseptor hingga membuat akseptor drop out. Penelitian ini bertujuan untuk mengetahui hubungan lama penggunaan kontrasepsi suntik dengan kejadian amenore. Metode penelitian cross sectional. Variabel independen yaitu lama penggunaan kontrasepsi suntik, variabel dependen yaitu kejadian amenore. Populasi dalam penelitian ini adalah seluruh pengguna kontrasepsi suntik di $R W$ 06 Kelurahan Campaka. Teknik pengambilan sampel dengan purposive sampling dengan. 
Jumlah sampel penelitian yaitu 56 orang. Instrumen yang digunakan pada kedua variabel ini adalah pedoman wawancara dan rekam medis. Analisis menggunakan uji Chi Square. Hasil penelitian terdapat hubungan antara lama penggunaan kontrasepsi suntik dengan kejadian amenore, dengan $p$ value 0,000. Sebagai pencegahan terjadinya droup out pada akseptor, maka sebaiknya konseling yang dilakukan oleh tenaga kesehatan lebih diutamakan dan berfokus pada penggantian metode kontrasepsi pada akseptor yang rentan terjadi drop out yaitu akseptor yang berusia $>35$ tahun

Kata Kunci : Kontrasepsi Suntik, amenore, akseptor

\section{PENDAHULUAN}

Kesehatan reproduksi adalah keadaan sehat secara fisik, mental, dan sosial secara utuh, tidak semata-mata bebas dari penyakit atau kecacatan, yang berkaitan dengan sistem, fungsi, dan proses reproduksi. Salah satu lingkup kesehatan reproduksi ialah pelayanan kesehatan ibu yang dilakukan agar ibu mendapat pelayanan kesehatan yang menunjang untuk hidup sehat dan mampu melahirkan generasi yang sehat dan berkualitas, serta mengurangi angka kematian ibu. Pelayanan kesehatan ibu diwujudkan dalam bentuk pengaturan kehamilan, pelayanan kontrasepsi, dan kesehatan seksual. Pengaturan kehamilan dan pelayanan kontrasepsi dilakukan dengan penyelenggaran program keluarga berencana.

Program keluarga berencana (KB) merupakan usaha untuk mengatur kehamilan, jumlah anak, dan jarak kelahiran anak untuk mewujudkan keluarga yang berkualitas. Program KB juga merupakan strategi untuk mengurangi angka kematian ibu khususnya dengan kondisi ibu yang 4T; terlalu muda melahirkan (dibawah usia 20 tahun), terlalu sering melahirkan, terlalu dekat jarak melahirkan, dan terlalu tua melahirkan (diatas usia 35 tahun). Selain itu program KB juga menimbulkan rasa aman, tentram dan menumbuhkan harapan untuk masa depan yang lebih baik dalam mewujudkan kesejahteraan lahir dan batin, sehingga apabila itu terwujud dapat meningkatkan kualitas dalam berkeluarga. Salah satu cara untuk mewujudkan program KB ini melalui metode kontrasepsi (Kemenkes RI, 2015).

Metode kontrasepsi terdiri dari metode sederhana dan modern. Metode modern terdiri dari kontrasepsi hormonal (pil, suntik, dan implant), alat kontrasepsi dalam rahim, dan kontrasepsi mantap. Metoda kontrasepsi suntik adalah metoda yang digunakan Wanita Usia Subur (WUS) dengan cara disuntikan melalui kulit yang dimasukan kedalam otot. 
Dalam penggunaannya, kontrasepsi suntik ini mempunyai 2 golongan, ada yang berisi hormon progestin dan ada juga yang berisi hormon kombinasi antara hormon progesteron dan estrogen (Hartanto, 2010). Kontrasepsi suntik yang digunakan WUS umumnya adalah yang penggunaannya 3 bulan sekali atau berisi progesteron dan disebut juga DMPA (Depo Medroxi Progesteronasetat).

Berdasarkan hasil penelitian oleh BKKBN Jawa Barat pada tahun 2013, penggunaan kontrasepsi di Jawa Barat di dominasi oleh penggunaan kontrasepsi suntik (37,0\%), pil KB (17,2\%), IUD/AKDR/spiral (5,1\%) (Riskesdas Jawabarat, 2013). Pengguna kontrasepsi suntik terbanyak di Provinsi Jawa Barat salahsatunya adalah di Kota Bandung. Menurut Badan Pemberdayaan Perempuan dan Keluarga Berencana Kota Bandung, jumlah penggunaan kontrasepsi suntik per bulan februari 2016 sebanyak 103.618 dari 254.366 akseptor KB aktif.

Besarnya penggunaan kontrasepsi hormonal diikuti dengan efek samping yang ditimbulkan dari hormon tersebut. Hasil Survey Demografi Dan Kesehatan Indonesia 2012 menyebutkan masalah kesehatan yang dikeluhankan oleh pengguna kontrasepsi suntik adalah tidak haid $(2,9 \%)$. Hal ini juga didukung penelitian Nuriyanah (2015) mengenai
Gambaran Lama Penggunaan KB Suntik Progestin dengan Kejadian Amenorrhea Sekunder di Dusun Karanglo dengan hasil dari 18 akseptor $\mathrm{KB}$ yag diteliti, 80\% menggunakan KB suntik DMPA $>1$ tahun dan sebagian besar mengalami amenore sebanyak $75 \%$.

Efek samping yang ditimbulkan terkadang menjadi suatu penyebab timbulnya masalah baru seperti droup out penggunaan alat kontrasepsi. Droup out (ketidaklangsungan pemakaian kontrasepsi) adalah akseptor yang menghentikan pemakaian kontrasepsi lebih dari 3 bulan Berdasarkan penelitian Maskanan (2009) faktor-faktor yang mempengaruhi droup out salah satunya adalah keluhan karena efek samping kontrasepsi.

Kecamatan Andir merupakan salah satu dari 3 daerah terbesar di Kota Bandung dalam penggunaan kontrasepsi suntik dan kelurahan Campaka penyumbang angka penggunaan tertinggi. Studi pendahuluan yang dilakukan peneliti melalui wawancara kepada PLKB (Petugas Lapangan KB) di kelurahan Campaka menyebutkan bahwa pengguna terbanyak kontrasepsi berada pada RW 06, serta tingginya angka kejadian droup out sebanyak 33 akseptor didukung dengan wilayah padat penduduk dan perekonomian warga yang menengah 
kebawah. Berdasarkan studi pendahuluan juga di RW 06 Kelurahan Campaka didapatkan 117 akseptor suntik. Dari 117 akseptor suntik sebanyak 80 akseptor mengalami amenore. Melalui wawancara pada 10 WUS, 7 orang pernah dan masih menggunakan kontrasepsi suntik $\geq 1$ tahun dengan keluhan tidak menstruasi sebanyak 4 orang dan 3 orang berhenti menggunakan KB suntik/drop out akibat amenore yang dialami. 3 orang lainnya menggunakan kontrasepsi suntik dengan pemakaian $<1$ tahun dan hanya mengeluh bercak-bercak darah dan haid tidak teratur. Studi lain juga menjelaskan bahwa $50 \%$ mengalami amenore setelah satu tahun pemakaian kontrasepsi suntik progestin (Varney, 2007)

Kejadian droup out ini akan menjadi masalah baru apabila dibiarkan, karena kejadian droup out pada usia lebih dari 35 tahun akan meningkatkan terjadinya kehamilan yang berisiko tinggi. Selain itu juga, droup out dapat menyebabkan pertumbuhan penduduk yang tidak terkendali.

\section{METODE}

Penelitian ini dengan pendekatan cross sectional. Populasi dalam penelitian ini adalah seluruh akseptor KB suntik di RW 06 Kelurahan Campaka Kota Bandung yaitu 117 Akseptor KB Suntik. Tempat dipilih karena Pengguna kontrasepsi yang terbanyak di Kelurahan Campaka adalah di RW 06. Angka kejadian droup out di RW ini sebanyak 33 akseptor.

Penentuan sampel yang digunakan pada penelitian ini menggunakan rumus (Nursalam,2014)

$$
n=\frac{N}{1+N(d)^{2}}
$$

Keterangan:

N : Besar Populasi

$\mathrm{n}$ : Besar Sampel

d : Tingkat signifikansi

Berdasarkan rumus tersebut, maka perhitungan sampel yang akan di ambil dengan tingkat signifikansi $0.1 \quad(10 \%)$ dapat dihitung sebagai berikut:

$$
\begin{aligned}
& n=\frac{117}{1+117(0,1)^{2}} \\
& n=53,917
\end{aligned}
$$

Berdasarkan perhitungan di atas, dapat diketahui besar sampel yang di gunakan dalam penelitian ini sebanyak 54. Untuk menghindari drop out maka jumlah sampel ditambah sehingga menjadi 56 responden Teknik pengambilan sampel menggunakan Purposive Sampling dengan cara mengambil subjek berdasarkan tujuan tertentu dan kriteria yang harus dipenuhi (Arikunto, 2013). Kriteria sampel yang diambil dalam penelitian ini adalah :

a. Kriteria Inklusi 
Akseptor KB Suntik yang lama penggunaan kontrasepsi dan efek menggunakan Depo Medroksi Progesteron samping yang ditimbulkan berdasarkan Asetat (DMPA)

b. Kriteria Ekslusi

1. Akseptor KB Suntik yang mempunyai gangguan sistem reproduksi

2. Akseptor KB Suntik yang mempunyai kebiasaan merokok pedoman wawancara yang sudah di uji melalui uji konten. Analisis menggunakan uji Chi Square. Waktu penelitian yang singkat sehingga perhitungan jumlah sampel dalam penelitian dengan nilai $\alpha$ 0,1 .

Dalam penelitian ini peneliti menggunakan teknik pengumpulan data dengan melakukan wawancara langsung mengenai

\section{HASIL DAN PEMBAHASAN}

Tabel 1 Distribusi Frekwensi Karaktristik Responden di RW 06 Kelurahan Campaka Kota Bandung Tahun 2016

\begin{tabular}{lcc}
\hline \multicolumn{1}{c}{ Karakteristik } & $\begin{array}{c}\text { Frekwensi } \\
\text { (f) }\end{array}$ & $\begin{array}{c}\text { Hasil Persentase } \\
(\%)\end{array}$ \\
\hline Usia & & \\
1. $\quad$ 20 Tahun & 0 & 0 \\
2. 20-30 Tahun & 24 & 42,86 \\
3. >30 Tahun & 32 & 57,14 \\
Paritas & & \\
1. 1 & 2 & 3.6 \\
2. 2-3 & 20 & 35.7 \\
3. >3 & 34 & 60.7 \\
Pendidikan & & \\
1. Dasar & 20 & 35.71 \\
2. Menengah & 35 & 62.5 \\
3. Tinggi & 1 & 1.79 \\
\hline
\end{tabular}

Berdasarkan tabel tersebut menunjukan bahwa sebagian besar responden berusia $>$ 30 tahun $(57,14 \%)$, sebagian besar mempunyai anak $>3$ yaitu 34 responden $(60,7 \%)$ dan sebagian besar berpendidikan menengah yaitu $62.5 \%$. 


\section{Tabel 2 Distribusi Frekwensi Lama Pemakaian Kontrasepsi Pada Akseptor Suntik Di RW 06 Kelurahan Campaka Kota Bandung}

Tahun 2016

\begin{tabular}{ccc}
\hline Lama Pemakaian & $\begin{array}{c}\text { Frekwensi } \\
\text { (f) }\end{array}$ & $\begin{array}{c}\text { Hasil Persentase } \\
(\mathbf{\%})\end{array}$ \\
\hline$<1$ Tahun & 17 & 30,4 \\
$\geq 1$ Tahun & 39 & 69,6 \\
\hline Jumlah & 56 & 100 \\
\hline
\end{tabular}

Berdasarkan tabel, menunjukan bahwa sebagian besar akseptor yang memakai kontrasepsi suntik $\geq 1$ tahun sebanyak 39 responden $(69,6 \%)$. Hasil penelitian yang didapat dari 56 akseptor kontrasepsi suntik di RW 06 Kelurahan Campaka Kota Bandung, sebagian besar akseptor memakai kotrasepsi suntik dengan lama $\geq$ 1 tahun sebanyak 39 (69,6\%). Kementerian Kesehatan RI (2013) menyatakan bahwa Kontrasepsi suntik yang merupakan bagian dari non-MKJP (Metode Kontrasepsi Jangka Panjang) memang tinggi penggunaannya dan semakin tahun penggunaan kontrasepsi non-MKJP ini semakin tinggi. Salah satu faktor yang mempengaruhi pemilihan dari kontrasepsi non-MKJP adalah umur PUS. Dari penelitian tersebut didapatkan penggunaan terbanyak adalah PUS usia kurang dari 30 tahun Hal tersebut berbeda dengan hasil penelitian ini dimana usia akseptor di RW 06 Kelurahan Campaka Kota Bandung di dominasi usia $>30$ tahun dimana salah satu tujuannya untuk mengakhiri kesuburan, hal ini sesuai dengan teori yang menyebutkan bahwa kontrasepsi suntik merupakan metode untuk salah satu tujuan kontrasepsi yaitu untuk mengakhiri kesuburan dengan kriteria kontrasepsi harus memiliki efektifitas tinggi dan kontrasepsi suntik memenuhi kriteria tersebut (Suratun, 2013). Walaupun pada masa mengakhiri kehamilan dan usia lebih dari 30 tahun di anjurkan penggunaan MKJP (Metode Kontrasepsi Jangka Panjang) seperti kontrasepsi mantap ataupun alat kontrasepsi dalam rahim (IUD), beberapa akseptor masih enggan dan lebih memilih penggunaan non-MKJP yang lain salah satunya adalah kontrasepsi suntik.

Untuk membatasi kehamilan/ mengakhiri kehamilan biasanya usia istri diatas 30 tahun. Pada usia tersebut juga sudah tidak dianjurkan untuk hamil disebabkan alasan medis, jadi memilih kontrasepsi suntik progestin menjadi suatu hal yang tepat karena apabila kontrasepsi suntik progestin dipakai terus menerus akan memperlambat terjadinya kesuburan dan pada usia ini angka kejadian 
morbiditas dan mortalitas akan tinggi apabila akseptor hamil (Hartanto, 2010).

Selain pertimbangan usia dalam menggunakan kontrasepsi suntik pendidikan juga berpengaruh dalam menentukan seseorang menggunakan kontrasepsi suntik, bila melihat hasil penelitian dimana akseptor di RW 06 Kelurahan Campaka Kota Bandung sebagian besar berpendidikan menengah keatas yang memungkinkan mempengaruhi pengetahuan mereka mengenai efek samping dari penggunaan kontrasepsi suntik. Seperti dalam penelitian dari Putriningrum (2012) mengenai faktor-faktor yang mempengaruhi ibu dalam pemilihan kontrasepsi KB suntik yaitu terdapat empat faktor yang mempengaruhi seperti faktor pengetahuan, faktor pendidikan, faktor jumlah anak, faktor peran suami. Peningkatan peran/partisipasi pasangan akan meningkatkan komunikasi dan pada akhirnya akan meningkatkan kepercayaan perempuan dalam memutuskan penggunaan kontrasepsi (Samandari, Speizer, \& O’Connel, 2010). Dukungan informasi, berupa saran, nasehat dan informasi lain yang diperlukan individu Hasil penelitian dari Nuriyanah (2015) membahas mengenai sebab akseptor menggunakan kontrasepsi suntik dalam waktu lama, terdapat beberapa alasan seperti kemudahan dalam penggunaan kontrasepsi suntik, usia yang sesuai untuk mengakhiri kehamilan, efek samping yang masih dapat diterima, dan tidak mengganggu aktivitas bekerja. Penelitian ini juga sama dengan yang di bahas oleh Bazargani (2006) menyatakan dari 411 orang yang tidak menstruasi $73,4 \%$ menyatakan puas dengan kondisi mereka yang tidak menstruasi. Oleh sebab itu mereka melajutkan pemakaian dalam 6 bulan selanjutnya

Tabel 3 Distribusi Frekwensi Kejadian Amenore Pada Akseptor Di RW 06 Kelurahan Campaka Kota Bandung Tahun 2016

\begin{tabular}{ccc}
\hline Kejadian Amenore & $\begin{array}{c}\text { Frekwensi } \\
\text { (f) }\end{array}$ & $\begin{array}{c}\text { Hasil Persetase } \\
(\mathbf{\%})\end{array}$ \\
\hline Tidak Amenore & 20 & 35,7 \\
Amenore & 36 & 64,3 \\
\hline Jumlah & 56 & 100 \\
\hline
\end{tabular}

Berdasarkan tabel sebagian besar akseptor suntik di RW 06 Kelurahan Campaka Kota Bandung mengalami amenore (64,3\%). Kejadian amenore pada akseptor kontrasepsi suntik di RW 06 Kelurahan Campaka Kota Bandung 
terdapat 36 responden $(64,3 \%)$ akseptor yang mengalami amenore selama pemakaian kontrasepsi suntik. Amenore merupakan salah satu efek samping yang terjadi pada akseptor di RW 06 Kelurahan Campaka Kota Bandung. Selain itu beberapa yang tidak amenore mengalami efek samping yang lain seperti spotting, perdarahan tidak teratur, berat badan naik hingga pusing. Ini sesuai dengan teori yang dijelaskan oleh Saifuddin (2006) bahwa efek samping yang ditimbulkan dari pemakaian kontrasepsi suntik DMPA adalah gangguan haid meliputi spotting, perdarahan tidak teratur, amenore, selain itu terdapat peningkatan berat badan, sakit kepala, nyeri payudara, dan lain-lain.

Banyaknya efek samping seperti gangguan haid terutama amenore diakibatkan karena cara kerja kontrasepsi hormonal berpengaruh pada organ seks wanita, terutama ovarium dan endometrium. Pada akseptor suntik, pada awal pemakaian mengalami gangguan haid berupa menstruasi tidak teratur ataupun spotting hingga semakin lama menjadi tidak menstruasi/amenore. Menstruasi tidak teratur ataupun spotting berlangsung pada suntikan pertama ataupun kedua DMPA, setelah suntikan ke tiga akseptor mengalami amenoroe. Hal ini memang bertahap seperti yang dijelaskan
Varney (2007) bahwa perdarahan tidak teratur dan bercak darah berlangsung selama seminggu atau lebih dan berangsur hilang hingga menjadi amenore.

Amenore yang terjadi pada penggunaan kontrasepsi suntik DMPA disebabkan defisiensi hormon gonadotropin. Menurut Hacker (2001) hormon gonadotropin ditentukan oleh dua pusat di hipotalamus, yaitu tonic centre dan cyclic centre. Tonic centre bekerja sebagai pengatur produksi FSH dan LH. Sedangkan cyclic centre bertanggung jawab dalam peningkatan hormon gonadrotropin khususnya LH. Pada kasus amenorea di hipotalamus fungsi cyclic centre terganggu, hanya tonic centre yang berfungsi sehingga hormon gonadotropin dapat terbentuk tetapi tidak cukup menimbulkan ovulasi karena defisiensi hormon goadotropin (Husni, 2010).

Pada pemberian kotrasepsi suntik DMPA, hormon progestin yang diberikan mempegaruhi FSH dan LH walapun belum berpengaruh banyak, sehingga pada awal pemakaian akseptor masih mengalami haid walaupun dengan interval yang berubah, ataupun spotting. Sesuai dengan penelitian dilakukan oleh dari Husni (2010) mengenai pengaruh pemakaian kontrasepsi suntik terhadap kejadian amenore bahwa terdapat pengaruh dari penggunaan kontrasepsi suntik terhadap kejadian 
amenore. Didukung oleh penelitian Putri (2014) mengenai kejadian ameorea pada akseptor KB suntik yang menyebutkan kejadian amenore cenderung timbul pada penggunaan kontrasepsi suntik DMPA. Selain itu, hormon progesteron pun mempengaruhi kerja di hipofisis anterior yang menghasilkan retensi FSH dan LH, retensi FSH dan LH ini akan menghambat pertumbuhan folikel sehingga menstruasi tidak terjadi.

\section{Tabel 4 Hubungan Lama Pemakaian Kontrasepsi Suntik Dengan Kejadian Amenore Pada Akseptor Akseptor Suntik Di RW 06 Kelurahan Campaka Kota Bandung} Tahun 2016

\begin{tabular}{|c|c|c|c|c|c|c|c|c|}
\hline \multirow{3}{*}{$\begin{array}{l}\text { Lama Pemakaian } \\
\text { Kontrasepsi Suntik }\end{array}$} & \multicolumn{4}{|c|}{ Kejadian Amenore } & & & \multirow{3}{*}{ OR } & \multirow{3}{*}{$p$ value } \\
\hline & \multicolumn{2}{|c|}{$\begin{array}{c}\text { Tidak } \\
\text { Amenore }\end{array}$} & \multicolumn{2}{|c|}{ Amenore } & \multicolumn{2}{|c|}{ Total } & & \\
\hline & $\mathrm{f}$ & $\%$ & $f$ & $\%$ & $\mathrm{f}$ & $\%$ & & \\
\hline$<1$ Tahun & 13 & 76,5 & 4 & 23,5 & 17 & 100 & & \\
\hline$\geq 1$ Tahun & 7 & 17,9 & 32 & 82,1 & 39 & 100 & 14,857 & 0,000 \\
\hline Jumlah & 20 & 35,7 & 36 & 64,3 & 56 & 100 & & \\
\hline
\end{tabular}

Hasil analisis pada tabel diatas menunjukan bahwa dari 39 akseptor yang memakai kontrasepsi suntik $\geq 1$ tahun, 32 $(82,1 \%)$ akseptor mengalami amenore. Sedangkan dari 17 akseptor yang memakai kontrasepsi suntik $<1$ tahun, ada 4 $(23,5 \%)$ akseptor yang mengalami amenore.

Hasil uji statistik diperoleh nilai $p$ value $=0,000$ pada $\alpha=0,1$ yang dapat diartikan $0,000 \leq 0,1(p \leq \alpha)$. Sehigga Ho ditolak dan Ha gagal ditolak, maka dapat disimpulkan bahwa terdapat hubungan antara lama pemakaian kontrasepsi suntik dengan kejadian amenore. Dari hasil analisis juga didapatkan $\mathrm{OR}=14,857$ yang menunjukan bahwa akseptor yang menggunakan kontrasepsi suntik dengan lama $\geq 1$ tahun mempunyai peluang 14,857 kali mengalami amenore dibandingkan dengan akseptor yang menggunakan $<1$ tahun.

Berdasarkan hasil penelitian dari 39 akseptor yang memakai kontrasepsi suntik $\geq 1$ tahun, 32 responden $(82,1 \%)$ akseptor mengalami amenore. Sedangkan dari 17 akseptor yang memakai kontrasepsi suntik $<1$ tahun, ada $4(23,5 \%)$ akseptor yang mengalami amenore dalam penggunaan kontrasepsi suntik DMPA. Uji Chi Square menunjukan bahwa terdapat hubungan antara lama pemakaian kontrasepi suntik DMPA dengan kejadian amenore di RW 06 Kelurahan Campaka Kota Bandung 
dengan nilai $\mathrm{p}$ value 0,000 dan hasil Odds Ratio $=14,857$ yang menunjukan bahwa akseptor yang menggunakan kontrasepsi suntik dengan lama $\geq 1$ tahun mempunyai peluang 14,857 kali mengalami amenore dibandingkan dengan akseptor yang menggunakan $<1$ tahun. Hasil penelitian ini menunjukan amenore kebanyakan dialami oleh pemakaian kontrasepsi suntik dengan lama $\geq 1$ tahun walaupun ada beberapa yang mengalami amenore $<1$ tahun. Kejadian gangguan menstruasi ini bertahap dari perdarahan tidak teratur, spotting hingga tidak terjadi menstruasi/amenore, hal ini disebabkan kadar hormone progesterone dalam darah bertahap dalam tubuh. sesuai dengan teori Kaunitz (2001, dalam Munayarokh 2014) kadar obat kontrasepsi DMPA yang dilepaskan secara perlahan dalam serum darah akan bersirkulasi dalam darah, sehingga mampu menekan pembentukkan hormon gonadotropin di hipotalamus. Teori Guyton \& Hall menyatakan pemberian kontrasepsi hormonal berpengaruh kepada efek umpan balik positif estrogen (estrogen positive feedback) dan umpan balik negative progesterone (progesterone negative feedback). Pada pemberian obat kontrasepsi suntik yang berisi hormon progesterone menyebabkan peningkatan kadar progesteron di dalam darah, hal ini terdeteksi oleh hipofisis anterior dan menimbulkan umpan balik negative dengan menurunkan sekresi hormon FSH dan LH.

Pada pemakaian pertama dan kedua, akseptor mengalami ketidaknormalan menstruasi ataupun spotting. Hal ini disebabkan hormone progesterone masih sedikit, mengacaukan perkembangan folikel pada tahap ovulasi. Pada penggunaan selanjutnya kadar progesterone sudah terlalu banyak dalam darah sehingga megacaukan pada pusat pengaturan hormone yaitu di hipotalamus anterior dan menyebabkan retensi FSH dan LH sehingga tidak terdapat perkembangan folikel dan menyebabkan amenore. Penelitian Riyanti (2011) mengenai hubungan lama penggunaan depo medroxyprogesteron acetat dengan kejadian amenorea sekunder dengan hasil $p$ value 0,048 yang menunjukan ada hubungan atara lama penggunaan depomedroxy progesteron acetat dengan kejadian amenore sekunder. Sama halnya dengan penelitian Trisnawati (2015) mengenai Tinjauan lama pemakaian kontrasepsi Depo Medroxy Progesteron Acetate berdasarkan kejadian amenore dengan $\mathrm{p}$ value 0,001 yang menujukan adanya hubungan antara lama pemakaian 
kontrasepsi DMPA dengan kejadian amenore.

Pemakaian kontrasepsi suntik yang lama memberikan efek samping yang berbeda-beda pada akseptor. Berdasarkan penelitian yang dilakukan di RW 06 Kelurahan Campaka Kota Bandung, sebagian besar kejadian amenore terjadi pada pemakaian kontrasepsi suntik $\geq 1$ tahun. Sama seperti hasil penelitian Munayarokh (2014) yang menyatakan bahwa terdapat hubungan lama pemakaian kontrasepsi suntik dengan gangguan amenore dengan $\mathrm{p}$ value 0,007 dimana gangguan menstruasi yang paling banyak dialami adalah amenore dan seluruhnya dialami oleh akseptor dengan penggunaan lebih dari 1 tahun.

Kebanyakan akseptor sudah mengetahui efek samping ini karena sudah dijelaskan oleh petugas kesehatan, tetapi beberapa orang masih merasa takut. Varney (2007) menjelaskan bahwa kejadian amenore sebanyak lima puluh persen terjadi pada pemakaian satu tahun. Respon akseptor berbeda-beda, ada yang merasa senang karena tidak mengalami menstruasi dan ada yang khawatir karena beberapa akseptor menganggap tidak menstruasi sebagai tanda dari kehamilan atau dari suatu penyakit.

\section{SIMPULAN}

Pada pelayanan kesehatan baik puskesmas, rumah sakit maupun bidan praktek swasta dapat memberikan konseling terutama efek samping penggunaan kontrasepsi seperti amenore sehingga kejadian drop out dapat dicegah.Penelitian ini dapat dikembangkan untuk penelitian lebih lanjut tentang hubugan lama penggunaan kontrasepsi suntik dengan efek samping yang lain yang mungkin timbul dari penggunaan kontrasepsi suntik.

\section{DAFTAR RUJUKAN}

Ambarwati . 2012. Pengaruh Pengaruh Kontrasepsi Hormonal Terhadap Berat Badan dan Lapisan Lemak Pada Akseptor Kontrasepsi Suntik DMPA di Polindes Mengger Karanganyar Ngawi. Skripsi. Surakarta: Universitas Muhammadiyah Surakarta

Arikunto, S. 2013. Prosedur Penelitian. Jakarta: Rineka Cipta

Bazargani, 2006. Amenorrhea: An Advantage Rather Than a Complication of Depot Medroxy Progesteron Acetat Injetable Contraceptive. International Journal of Pharmacology.2 (3). 352-256

Baziad, A. 2008. Kontrasepsi Hormonal. Jakarta: PT Bina Pustaka Sarwono Prawihardjo

Clark, M. D. 2005. Weight, Fat Mass, and Central Distribution of Fat Increase 
When Women use Depotmedroxy progesteron Acetat for Contraception.International Journal of Obesity.29. 1252-1258

Hartanto, Hanafi. 2010. Keluarga Berencana dan Kontrasepsi. Jakarta: Pustaka Sinar Harapan.

Hastono, 2006. Analisis Data. Universitas Indonesia

Hidayat, A . 2014. Metode Penelitian Keperawatan dan Teknik Analisi Data. Jakarta: Salemba Medika

Husni, Ervi. Herlina, Netti. 2010. Pengaruh Pemakaian Kontrasepsi Suntik terhadap Kejadian Amenorhea di BPS Farida Hajri Surabaya. Jurnal Penelitian Poltekkes Depkes Surabaya. 8 (2). 93-97

Kementerian Kesehatan Republik Indonesia. 2012. Survei Demografi dan Kesehatan Indonesia. Jakarta

Kementerian Kesehatan RI.2013 .Riskesdas Dalam Angka Jawa Barat .Badan Penelitian dan Pengembangan Kesehatan

Kementerian Kesehatan Republik Indonesia. 2013.. Buletin Jendela: Data dan Informasi Kesehatan. Jakarta

Kementerian Kesehatan Republik Indonesia. 2015. Profil Kesehatan Indonesia Tahun 2014. Jakarta

Manuaba, . 2010. Ilmu Kebidanan, penyakit kandungan, dan KB untuk pendidikan bidan. Jakarta:EGC
Munayarokh. 2014. Hubungan Lama Pemakaian Kontrasepsi Suntik DMPA dengan Gangguan Menstruasi Di BPM Mariyah Nurlaili, Rambe Anak Mungkid..Jurnal Kebidanan. 3 (6). 50-56

Nasution, 2011. Faktor-faktor yang Mempengaruhi Penggunaan MKJP di Enam Wilayah. Jakarta: Pusat Penelitian Pengembangan KB dan Keluarga Sejahtera BKKBN.

Notoatmojo, S.2003. Pendidikan dan Perilaku Kesehatan. Jakarta: Rineka Cipta

Nursalam. 2014.Metodologi Penelitian Ilmu Keperawatan: Pendekatan Praktis. Edisi 3. Jakarta: Salemba Medika

Nuriyanah, 2015. Gambaran Lama Penggunaan KB Suntik Progestin dengan Kejadian Amenorrhea Sekunder Di Dusun Karanglo Desa Driyorejo Gresik. Midweferia.1 (1). 7-15

Pendit, Brahm U. 2012. Ragam Metode Kontrasepsi. Jakarta: EGC

Pinasti, Anisa Putri. 2013. Pengaruh Penggunaan kontrasepsi Suntik Terhadap Peningkatan Berat Badan dan Kenaikan tekanan Darah pada Akseptor KB di Puskesmas Kecamatan Sukodono Kabupaten Sragen. Skripsi. Surakarta: Fakultas Farmasi Universitas Muhammadiyah Surakarta. 
Prawirohardjo, 2013. Ilmu Kebidanan. Jakarta: PT Bina Pustaka Sarwono Prawirohardjo

Putriningrum, Rahajeng. 2012. Faktorfaktor yang Mempengaruhi Ibu dalam Pemilihan Kontrasepsi Suntik di BPS, Ruvina Surakarta. Karya Tulis Ilmiah. Surakarta: STIKes Kusuma Husada Surakarta.

Putri, Resti A. 2015. Kejadian Amenore pada Akseptor KB Suntik di BPM CH Susilowati, Treko, Mungkid. Jurnal Kebidanan. 4 (8). 57-61

Riyanti, Septi. 2011. Hubungan Lama Penggunaan Depo Medroxyprogesteron acetat dengan Kejadian Amenore Sekunder Pada Akseptor Suntik di BPS Sumarni Pundong Bantul.Skripsi. Yogyakarta.

Saifuddin, Abdul Bari. et. al. 2012. Buku Panduan Praktis Pelayanan Kontrasepsi. Edisi Kedua Jakarta: Yayasan Bina Pustaka Sarwono Prawirohardjo.

Samandari, G., Speizer, I. S., \& O'Connell, K. (2010). The role of social support and parity on contraceptive use in cambodia. International Perspectives on Sexual and Reproductive Health, 36(3), 12231.

Sulistyawati, Ari. 2014. Pelayanan Keluarga Berencana. Jakarta: Salemba Medika

Suratun. 2013. Pelayanan Keluarga Berencana dan Pelayanan Kontrasepsi. Jakarta: Trans Info Media

Trisnawati, 2015. Tinjauan Pemakaian Kontrasepsi Depo Medroxy Progesteron Acetat Berdasarkan Kejadian Amenore. Gaster. 12 (1). 19-27

Varney, Helen. Kriebs, et.al. 2007. Buku Ajar Asuhan Kebidanan.Volume 1. Edisi 4. Jakarta: EGC

Zaelani, Ahmad. 2011. Faktor-faktor yang Mempengaruhi Tingkat Sosial Ekonomi Masyarakat Desa Perhiasan Kecamatan Selesai Kabupaten Langkat. Skripsi: Sumatra: Universitas Sumatra Utara 
